\title{
Perbandingan Kadar Gula Darah Puasa pada Anak Obes dengan Resistensi Insulin dan Tanpa Resistensi Insulin
}

\author{
Yose M. Pangestu, Antolis, Vivekenanda Pateda, Kristellina T, Sarah M. Salendu Warouw \\ Bagian Ilmu Kesehatan Anak Fakultas Kedokteran Universitas Sam Ratulangi/RSU Prof. R. D. Kandou, \\ Manado
}

\begin{abstract}
Latar belakang. Obesitas pada anak semakin banyak terjadi pada usia sekolah. Anak obes berisiko terjadi diabetes mellitus tipe-2 di kemudian hari. Peningkatan kadar gula darah puasa anak obes terutama yang mengalami resistensi insulin.

Tujuan. Mengetahui perbedaan kadar gula darah puasa pada anak obes dengan resistensi insulin dibanding anak obes tanpa resistensi insulin.

Metode. Dilakukan penelitian dengan menggunakan metode penelitian analitik observasional dengan pendekatan potong lintang.

Hasil. Didapatkan 54 anak obes, rerata usia 12,2 (11,9-12,5) tahun. Tigapuluh empat $(63 \%)$ anak mengalami resistensi insulin, di antaranya $23(67,6 \%)$ berjenis kelamin laki-laki. Rerata kadar gula darah puasa anak obes dengan resistensi insulin lebih tinggi bermakna dibanding anak obes tanpa resistensi insulin 5,08 $(4,9-5,2) \mathrm{mmol} / \mathrm{L}$ vs 4,79 (4,6-4,9) $\mathrm{mmol} / \mathrm{L} \quad(\mathrm{p}<0,003)$.

Kesimpulan. Anak obes dengan resistensi insulin memiliki kadar gula darah puasa lebih tinggi dibanding anak obes tanpa resistensi insulin. Sari Pediatri 2013;15(3):161-6.
\end{abstract}

Kata kunci: resistensi insulin, kadar gula darah puasa, obes

A

ngka kejadian diabetes melitus tipe-2 pada anak di beberapa tahun terakhir ini semakin meningkat seiring dengan peningkatan angka kejadian obesitas. Peningkatan

\footnotetext{
Alamat korespondensi:

Dr. Vivekenanda Pateda, Sp.A(K), Bagian Ilmu Kesehatan Anak Fakultas Kedokteran Universitas Sam Ratulangi/RSU Prof. R. D. Kandou, Manado. Jl. Raya Tanawangko Malalayang, Manado, SULUT. Telp. (0431) 821652. E-mail: vivepateda@idai.or.id
}

tersebut sejalan dengan perubahan gaya hidup, yaitu konsumsi makanan tinggi karbohidrat dan lemak yang meningkat, berkurangnya aktivitas fisik akibat kemajuan teknologi yang menyediakan berbagai macam permainan anak yang kurang menuntut aktivitas fisik anak. ${ }^{1,2}$

Diabetes melitus tipe-2 terjadi akibat resistensi insulin, yaitu ketidakmampuan insulin untuk menghasilkan efek biologik secara normal, ditandai dengan peningkatan jumlah insulin puasa yang 
kemudian akan menyebabkan terjadinya peningkatan kadar gula darah. Diabetes melitus tipe-2 yang tidak terdeteksi dan ditangani secara dini akan mengakibatkan komplikasi jangka panjang, baik makrovaskular maupun mikrovaskular. Risiko resistensi insulin meningkat pada anak-anak dengan berat badan lebih atau obes, mempunyai riwayat diabetes melitus tipe-2 dalam keluarga, berasal dari ras tertentu, dan anak-anak dalam masa pubertas. $^{3-6}$

Peningkatan prevalensi obesitas dan angka kejadian DM tipe-2 pada anak, maka identifikasi dini pada anak dengan faktor risiko tersebut sangat penting, sehingga dapat dilakukan intervensi dini. Di Indonesia, belum terdapat panduan tentang skrining pada anak obes, terutama pada anak dengan risiko DM tipe-2. Banyak anak dan remaja dengan resistensi insulin dan DM tipe-2 asimptomatis tidak memiliki gejala klasik seperti poliuria dan polidipsi. Skrining direkomendasikan pada anak obes yang memiliki satu atau lebih faktor risiko, seperti (1) berat badan lebih, (anak dengan indeks massa tubuh >persentil 85 untuk usia dan jenis kelamin), (2) riwayat keluarga DM tipe-2 atau diabetes pada kehamilan, (3) ras/etnis (Amerika Indian, ras Afrikadi Amerika, Hispanik, orang Asia), dan (4) adanya tanda resistensi insulin atau kondisi berkaitan dengan resistensi insulin (akantosis nigrikans, hipertensi, dislipidemia) dan pemeriksaan nilai kadar gula darah puasa. ${ }^{6}$ Nilai kadar gula darah puasa normal, tetapi dalam rentang tinggi berisiko sebagai tahap awal anak mengalami resistensi insulin (pre-prediabetes). ${ }^{7}$ Atas dasar pemikiran ini, maka penelitian ini dilakukan untuk mengetahui apakah ada perbedaan bermakna nilai gula darah puasa pada anak obes dengan resistensi insulin dan tanpa resistensi insulin. Hal tersebut dapat membantu skrining sederhana anak berisiko terjadinya resistensi insulin dalam upaya mencegah DM tipe-2 di kemudian hari dengan intervensi sedini mungkin.

\section{Metode}

Penelitian analitik dengan pendekatan potong lintang dilakukan di 14 SD dan 8 SMP di Kecamatan Wenang Kota Manado. Subjek dipilih secara random, mulai bulan Oktober 2009 sampai dengan Januari 2010.
Sampel minimal dihitung berdasarkan rumus korelatif (digunakan $\alpha=0,05, \beta=0,20$ dan $\mathrm{r}=0,4$ ) didapat 37 sampel. Kriteria inklusi adalah anak obes, anak kandung, orang tua menyetujui ikut serta, dan bersedia mengisi formulir penelitian. Kriteria eksklusi adalah anak tidak puasa saat pengambilan sampel darah, riwayat berat lahir rendah, menderita sindrom Cushing, menderita penyakit keganasan, sedang menjalani pengobatan kortikosteroid atau obat anti diabetik, dalam pengobatan asam nikotinat. Obes ditentukan berdasarkan indeks massa tubuh (IMT) yang dihitung dengan membagi berat badan (dalam kilogram) dengan kuadrat tinggi badan (dalam meter). Diagnosis obesitas ditetapkan bila IMT lebih dari +3SD dari kurva IMT referensi pertumbuhan anak WHO 2007 untuk anak dan remaja berusia 5-19 tahun sesuai dengan jenis kelamin. ${ }^{8,9}$

Variabel penelitian meliputi usia, jenis kelamin, kadar gula darah puasa, kadar insulin puasa. Pengumpulan data dilakukan dengan teknik wawancara dengan orang tua dari anak yang telah menjadi sampel penelitian. Pemeriksaan sampel darah berupa pemeriksaan kadar insulin dan kadar gula darah puasa. Sebelum pengambilan sampel darah, anak harus puasa selama 8 jam (anak tidak boleh makan atau minum apapun selain air putih). Hasil sampel serum darah selanjutnyaldikirim langsung oleh laboratorium kepada peneliti, kemudian dicatat dalam formulir data yang telah dipersiapkan. Penghitungan sensitivitas insulin menggunakan metode Homeostasis Model Assessment of Insulin Resistance Index (HOMAIR) berdasarkan kadar insulin puasa dan kadar gula darah puasa, dengan rumus: HOMA-IR = insulin $(\mu \mathrm{U} / \mathrm{mL}) \times$ [gula $(\mathrm{mmol} / \mathrm{L}) / 22,5]$. Diagnosis resistensi insulin ditegakkan apabila nilai $\mathrm{HOMA} \geq 2,6 .{ }^{10-12}$ Kemudian dibandingkan nilai rerata kadar gula darah puasa dengan resistensi insulin dan tanpa resistensi insulin. Pembandingan menggunakan analisis statistik komparatif data kuantitatif t-test. Data yang dikumpulkan diolah dengan menggunakan program SPSS versi 17, dengan tingkat kemaknaan $<0,05$.

\section{Hasil}

Siswa yang diikutsertakan dalam penelitian 7752 anak, 123 anak obes di antaranya berusia 10-14 tahun, terdiri dari 71 anak laki-laki dan 52 anak perempuan. Setelah dilakukan wawancara dan pemeriksaan fisik, 
ditetapkan 55 orang anak yang memenuhi kriteria inklusi. Karena 1 orang anak menolak pengambilan sampel darah, maka hanya 54 orang anak yang diikutsertakan. Karakteristik hasil penelitian menurut jenis kelamin, usia tertera pada Tabel 1 .

Dari 54 anak obes, didapat rerata usia 12,2 (11,9-12,5) tahun. Tigapuluh tujuh $(68,5 \%)$ anak laki-laki dan 17 (31,5\%) anak perempuan. Tigapuluh empat (63\%) anak mengalami resistensi insulin, 23 $(67,6 \%)$ berjenis kelamin laki-laki, dan $11(32,4 \%)$ anak perempuan. Rerata kadar gula darah puasa pada anak obes dengan resistensi insulin lebih tinggi bermakna dibanding tanpa resistensi insulin 5,08 $(4,9-5,2) \mathrm{mmol} / \mathrm{L}$ dibanding 4,79(4,6-4,9) $\mathrm{mmol} / \mathrm{L}$, $(\mathrm{p}<0,003)$. an lemak yang menginduksi resistensi insulin dan intoleransi gula mulai muncul. Serta akumulasi lemak visceral disertai resistensi jaringan lemak terhadap insulin dan peningkatan kepekaan terhadap katekolamin. Penyerapan gula dan asam lemak bebas (FFA) oleh jaringan lemak berkurang, tingkat lipolisis meningkat, dan clearance trigliserida (TG) terganggu karena downregulation lipoprotein lipase. Resistensi terhadap insulin tampaknya dimediasi oleh perubahan dalam ekspresi sitokin jaringan lemak. Temuan lain menunjukkan bahwa FFA, sitokin, dan glukosa dapat menyebabkan disfungsi sel- $\beta$ pada individu dengan predisposisi genetik. Dengan demikian, peningkatan kronis FFA mungkin berkontribusi terhadap kerusakan sel- $\beta$ pada anak obes dengan resistensi

Tabel 1. Karakteristik sampel penelitian

\begin{tabular}{lcccc}
\hline \multirow{2}{*}{ Karakteristik } & \multicolumn{3}{c}{ Resistensi insulin } \\
\cline { 2 - 5 } & \multicolumn{3}{c}{ Negatif } & Positif \\
\hline Jenis kelamin & $\mathrm{n}$ & $\%$ & 23 & 67,6 \\
$\quad$ Laki-laki & 14 & 70 & 11 & 32,4 \\
Perempuan & 6 & 30 & & \\
Usia (tahun) & & & 6 & 17,6 \\
$10-<11$ & 2 & 10 & 9 & 26,5 \\
$11-<12$ & 9 & 20 & 7 & 20,6 \\
$12-<13$ & 4 & 25 & 10 & 29,4 \\
$13-<14$ & 5 & 0 & 2 & 5,9 \\
$14-<15$ & 0 & & & \\
\hline
\end{tabular}

Tabel 2. Perbandingan kadar gula darah puasa antara anak obes dengan resistensi insulin dan tanpa resistensi insulin

\begin{tabular}{lccc}
\hline Resistensi insulin & Rata-rata GDP* & SB & $\mathrm{p}$ \\
\hline Ya & $5,08 \mathrm{mmol} / \mathrm{L}$ & 0,391 & $<0,003$ \\
Tidak & $4,79 \mathrm{mmol} / \mathrm{L}$ & 0,276 & \\
\hline
\end{tabular}

$\mathrm{GDP}=$ kadar gula puasa

\section{Pembahasan}

Obesitas dan resistensi insulin dikenal sebagai faktor risiko terjadi DM tipe-2, penyakit kardiovaskular, aterosklerotik, dan hipertensi. Lebih lanjut, obesitas biasanya dikaitkan dengan resistensi insulin. Namun, apakah obesitas terjadi pada awal atau setelah hiperinsulinemia masih belum diketahui pasti. Secara konseptual, mekanisme yang diusulkan untuk menjelaskan kausalitas adalah mekanisme penumpuk- insulin yang memang genetik predisposisi diabetes tipe-2. Mekanisme lipid menyebabkan efek toksik ("lipotoxicity") pada fungsi sel $\beta$-tetap tidak jelas. FFA dan sitokin seperti TNF- $\alpha$ dan IL-1 mungkin merusak fungsi $\beta$-sel secara langsung melalui induksi apoptosis sel- $\beta .{ }^{13}$

Rerata usia anak obes penelitian kami 12,2 tahun dengan rentang 11,9-12,5 tahun. Lebih dari separuh sampel anak obes berjenis kelamin laki-laki. Tigapuluh tujuh $(68,5 \%)$ anak laki-laki dan 17 (31,5\%) anak 
perempuan. Hasil berbeda pada penelitian Atabek ${ }^{14}$ yang mendapatkan anak obes lebih banyak pada anak perempuan sebesar $110(56,12 \%)$ dari sampel anak obes. Sedangkan penelitian Ikezaki $\mathrm{dkk}^{15}$ mendapatkan hal yang serupa, dari 105 anak obes yang diteliti $61 \%$ di antaranya adalah anak laki-laki dan 39\% anak perempuan. Penelitian oleh Brufani dkk, ${ }^{16}$ di sebuah klinik obesitas di Italia, juga ditemukan bahwa obesitas lebih banyak pada anak laki-laki $(56,7 \%)$ daripada anak perempuan (43,3\%). Pada penelitian kami, anak obes yang mengalami resistensi insulin didapatkan $34(63 \%)$ sampel, di antaranya $23(67,6 \%)$ berjenis kelamin laki-laki, dan 11 (32,4\%) anak perempuan. Hal tersebut lebih tinggi dibanding penelitian oleh Atabek yang didapat resistensi insulin 43\%, dengan proporsi terbanyak pada anak laki-laki $(54,2 \%) .{ }^{14}$ Secara etnis, penelitian dari Australia yang meneliti anak muda dari berbagai ras Kaukasia Eropa, China, Asia Tenggara, Asia Selatan, dan Arab mendapatkan bahwa ternyata dibanding ras kaukasia Eropa, anak muda dari Asia Tenggara memiliki kadar gula darah post-prandial tertinggi dan sensitivitas insulin terendah. ${ }^{17}$

Skrining pada anak dengan faktor risiko diabetes mellitus, selanjutnya mencangkup pemeriksaan kadar insulin puasa, gula darah puasa, tes toleransi glukosa 2 jam (setelah pemberian glukosa $1,75 \mathrm{~g} /$ $\mathrm{kg}$, maksimum $75 \mathrm{~g}$ ), dan pemeriksaan lipid darah. Telah dikemukakan bahwa anak yang mengalami gula darah puasa terganggu, secara klinis berrisiko tiga kali lipat terhadap terjadinya diabetes mellitus tipe2. ${ }^{18-19}$ Kriteria diagnosis gula darah puasa terganggu pertamakali didefinisikan oleh American Diabetes Association (ADA) tahun 1997, kadar gula darah puasa antara 110 dan $125 \mathrm{mg} / \mathrm{dL}$. September 2003, ADA merevisi definisi gula darah puasa normal, yaitu kurang dari $100 \mathrm{mg} / \mathrm{dL} .{ }^{20}$ Diabetes tipe- 2 manifes dari keadaan pre-diabetes, perkembangan progresif peningkatan toleransi glukosa terganggu (TGT), dan kadar gula darah puasa normal yang tinggi. ${ }^{21}$ Sekarang ini, dikenal dua keadaan pre-diabetes, yaitu TGT dan gula darah puasa terganggu. Subyek dengan kondisi di atas, cenderung secara progresif menjadi diabetes tipe-2 dengan rate per tahun sekitar $10 \% .{ }^{21}$ Konsensus International Diabetes Federation mengenai gula darah puasa terganggu dan TGT pada dewasa, disimpulkan bahwa $60 \%$ dewasa yang menjadi penderita diabetes sudah mengalami toleransi glukosa terganggu dan gula darah puasa terganggu dalam waktu 5 tahun sampai terjadinya diabetes. ${ }^{22}$ Sama halnya dengan penelitian di Finlandia dan Belanda, pada dewasa, didapatkan gula darah puasa terganggu merupakan faktor risiko independen untuk terjadinya diabetes. ${ }^{23,24}$ Penelitian di Belanda, 38\% dewasa dengan gula darah puasa terganggu dan $32,4 \%$ dengan TGT akan menjadi diabetes dalam periode 6 tahun. ${ }^{23}$ Perlu dilakukan penelitian lebih lanjut mengenai perjalanan penyakit tersebut pada anak dan dewasa yang mengalami gangguan kadar gula darah puasa untuk melihat risiko jangka panjang sampai terjadinya diabetes tipe- 2 . Belum diketahui bagaimana anak yang mengalami gula darah puasa terganggu sampai menjadi diabetes melitus tipe-2.

Penurunan sensitivitas, sekresi, dan indeks disposisi (ID) terjadi pada anak obes dan mengalami progresi menjadi TGT. Banyak para ahli menduga, perubahan sensitivitas insulin dan ID ini sudah tejadi pada subyek dengan peningkatan kadar gula darah puasa walaupun masih dalam batas normal. Dispekulasikan bahwa gula darah puasa normal yang tinggi $(>90$ $\mathrm{mg} / \mathrm{dL}$, pre-prediabetes) dan keadaan pre-diabetes (TGT dan gangguan gula darah puasa terganggu) merupakan derajat risiko disglisemia dan diabetes tipe2. ${ }^{25}$ Penelitian Malley dkk mengatakan bahwa kadar gula darah puasa normal tapi tinggi berkaitan dengan penurunan sensitivitas dan disfungsi sel beta. Hal tersebut juga didukung oleh penelitian pada dewasa yang mengidentifikasi peningkatan kadar gula darah puasa normal merupakan faktor independen terjadinya resistensi insulin dan diabetes tipe-2.25,26 Status kadar gula darah puasa merupakan 'good marker' dari respon insulin akut dan ID. ${ }^{27}$ Dihipotesiskan bahwa anak gemuk dengan peningkatan kadar gula darah puasa, odd rasio dari penurunan sensitivitas insulin, dan disregulasi sel beta serta profil penyakit jantung akan lebih tinggi. ${ }^{7}$ Penelitian Samuel $\mathrm{dkk}^{25}$ mendapatkan bahwa subyek dengan kadar nilai gula darah puasa $<90$ $\mathrm{mg} / \mathrm{dL}$ lebih toleran terhadap glukosa, dan lebih sensitif terhadap insulin dibanding subyek dengan kadar gula darah puasa yang lebih tinggi sekalipun masih dalam batas normal. Penelitian ini juga menyatakan bahwa pada subyek yang sehat, sensitivitas insulin bisa dilihat dari kadar gula darah puasa. Masih sedikit penelitian yang secara khusus meneliti mengenai ambang kadar gula darah penyebab gangguan yang signifikan kerja dan sekresi insulin di antara subyek dengan nilai kadar gula darah puasa normal rendah $(<90 \mathrm{mg} / \mathrm{dL})$, normal tinggi $(90-99 \mathrm{mg} / \mathrm{dL})$. Pada penelitian kami, 
dilihat kadar gula darah puasa pada subyek resistensi insulin, sehingga penelitian kami menggunakan insulin darah puasa dan kadar gula puasa selama survei. ${ }^{28}$ Sebuah penelitian longitudinal terbaru oleh Tirosh $\mathrm{dkk}^{29}$ melaporkan bahwa kadar gula darah puasa yang meningkat tapi masih rentang normal dapat menjadi risiko terjadinya diabetes melitus tipe- 2 dalam periode 10 tahun kemudian selama folow-up. Nichols $\mathrm{dkk}^{19}$ mengamati peningkatan risiko sebesar $6 \%$ terjadinya diabetes tiap peningkatan $0,06 \mathrm{mmol} / \mathrm{l} \mathrm{kadar}$ gula darah puasa, sampel dengan kadar gula darah puasa antara 5 dan $5,56 \mathrm{mmol} / \mathrm{l}$ memiliki risiko penyakit lebih besar daripada sampel dengan kadar gula darah puasa $<4,72 \mathrm{mmol} / \mathrm{l}$. Hal tersebut mendukung penemuan pada penelitian setelahnya. Pada penelitian kami, kadar gula darah puasa pasien obes yang mengalami resistensi insulin lebih tinggi bermakna dibanding anak obes tanpa resistensi insulin. Senada dengan penelitian Atabek yang mendapat kadar gula darah puasa pada kelompok resistensi insulin lebih tinggi bermakna dibanding anak obes tanpa resistensi insulin. ${ }^{14}$ Penelitian Samuel $\mathrm{dkk}^{25}$ mendapatkan HOMA-IR terjadi peningkatan bertahap yang signifikan di antara subyek yang mengalami resistensi insulin dari gula darah puasa rendah dibanding gula darah puasa normal yang tinggi, dan gula darah puasa terganggu. Sensitivitas insulin berhubungan terbalik dengan gula darah, bahkan pada gula darah puasa dalam rentang normal. Peningkatan kadar gula darah puasa dari 70 sampai $125 \mathrm{mg} / \mathrm{dL}$ berkaitan dengan $3 \mathrm{kali}$ penurunan sensitivitas insulin. Kelompok anak obes dengan resistensi insulin pada penelitian ini apabila dilihat dari kadar gula darah puasa $(>5 \mathrm{mmol} / \mathrm{L})$, menurut Nichols ${ }^{19}$ berisiko terjadinya diabetes melitus di kemudian hari walaupun belum terjadi gangguan gula darah puasa.

Mengingat morbiditas yang terkait dengan resistensi insulin dan DM tipe-2, para medis dan masyarakat awam menghadapi tantangan untuk mencegah, bukan hanya mengobati, komplikasi metabolik dan vaskular kronis pada pasien obes. Penelitian terbaru menunjukkan bahwa intervensi gaya hidup dapat mengurangi faktor risiko, dan kejadian diabetes melitus tipe-2 pada anak dan orang dewasa. Bahwa orang-orang yang mengalami pradiabetes juga dapat dikonversi kembali ke toleransi gula normal dengan manajemen gaya hidup yang sesuai. ${ }^{30}$ Penelitian kami membuktikan bahwa anak obes yang mengalami resistensi insulin memang memiliki kadar gula darah puasa lebih tinggi bermakna dibanding anak obes yang belum mengalami resistensi insulin. Upaya pencegahan dapat dilakukan sedini mungkin walaupun kadar gula darah puasa masih normal tetapi dalam rentang tinggi. Pengukuran kadar gula darah puasa sederhana bisa menjadi ukuran yang berguna untuk mengidentifikasi anak yang menjadi target skrining diabetes, dan siapa yang perlu dilakukan penanganan manajemen gaya hidup lebih awal.

\section{Kesimpulan}

Anak obes yang mengalami resistensi insulin memiliki kadar gula darah puasa lebih tinggi dibanding anak obes tanpa resistensi insulin. Pemeriksaan sederhana gula darah puasa dapat membantu mengidentifikasi anak obes yang mengalami resistensi insulin, sehingga intervensi lebih awal dapat diterapkan pada anak obes sejak dini untuk mencegah terjadinya diabetes melitus tipe 2 di kemudian hari.

\section{Daftar pustaka}

1. Sahay BK, Sahay RK. Type 2 diabetes in the young. Int J Diab Dev Ctries 2003;23:51-4.

2. Obesitas pada anak. Dalam: Soetjiningsih. Tumbuh kembang anak. Jakarta: EGC;1995; h.183-90.

3. Jones LH, Ficca M. Is acanthosis nigricans a reliable indicator for risk of type 2 diabetes? J Sch Nurs 2007;23:247-51.

4. Steinberger J, Daniels SR. Atherosclerosis, hypertension, and obesity in the young. Circulation 2003;107:144853.

5. DeFronzo RA, Bonadonna RC, Ferrannini E. Pathogenesis of non insulin dependent diabetes melitus: a balanced overview. Diabetes Care 1992;15:318-68.

6. Arslanian SA. Type 2 diabetes mellitus in children: pathophysiology and risk factors. J Pediatr Endocrinol Metab 2000;13:1385-94.

7. G. O'Malley. High normal fasting glucose level in obese youth: a marker for insulin resistance and beta cell dysregulation. Diabetologia 2010;53:1199-1209.

8. Onis M, Onyango AW, Borghi E, Siyam A, Nishida C, Siekmann J. Development of a WHO growth reference for school-aged children and adolescents. Bull World Health Organ 2007;85:660-7.

9. WHO. WHO child growth standards: growth velocity 
Yose M. Pangestu dkk: Kadar gula darah puasa pada anak obes

based on weight, length and head circumference: methods and development. Geneva: WHO;2009.

10. Hettihewa LM, Palangasinghe S, Jayasinghe SS, Gunasekara SW, Weerarathna TP. Comparison of insulin esistance by indirect methods - HOMA, QUICKI and McAuley - with fasting insulin in patients with type 2 diabetes in Galle, Sri Lanka: a pilot study. OJHAS 2006;5:1-8.

11. Hettihewa LM, Dharmasiri LP, Ariyaratne CD, Jayasinghe SS, Weerarathna TP, Kotapola IG. Significant correlation beween $\mathrm{BMI} / \mathrm{BW}$ with insulin resistance by McAuley, HOMA and QUICKI indices after 3 months of pioglitazone in diabetic population. Int J Diab Dev Ctries 2007;27:87-92.

12. Matthews DR, Hosker JP, Rudenski AS, Naylor BA, Treacher DF, Turner RC. Homeostasis Model Assessment: insulin resistance and beta-cell function from fasting plasma glucose and insulin concentrations in man. Diabetologia 1985;28:412-9.

13. Sathanur RS. Temporal association between obesity and hyperinsulinemia in children, adolescents, and young adults: The Bogalusa Heart Study. Metabolism 1999; 148:928-34.

14. Atabek ME. Assesment of abnormal glocose homeostasis and insulin resistence in Turkish obese children and adolescents. Metabolism 2007;9:304-10.

15. Ikezaki A, Miura N, Kikuoka N. Clinical characteristics of obese Japanese children with acanthosis nigricans. Clin Pediatr Endocrinol 2001;10: 47-52.

16. Brufani C, Ciampalini P, Grossi Al. Glucose tolerance statur ini 510 children and adolescents attending an obesity clinic in Central Italy. Pediatric Diabetes 2010;11:47-54.

17. Dickinson S, Colagiuri S, Farasmus E, Petocz P, Miller JC. Postprandial hyperglycemia and insulin sensitivity differ among lean young adults of different ethnicities. J Nutr 2002;132:2574-9.

18. Piche ME, Lemieux S, Perusse L, Weisnagel SJ. High normal 2-hour plasma glucose is associated with insulin sensitivityand secretion that may predispose to type 2 diabetes. Diabetologia 2005;48:732-40.

19. Nichols GA, Hillier TA, Brown JB. Normal fasting plasma glucose and risk of type 2 diabetes diagnosis. Am
J Med 2008;121:519-24.

20. Genuth S, Alberti KG, Bennett P, Buse J, Defronzo R, Kahn R, dkk. the expert committee on the diagnosis and classification of diabetes mellitus. Diabetes Care 2005;26:3160-7.

21. Vendrame F, Gottlieb PA. Prediabetes: prediction and prevention trials. Endocrinol Metab Clin North Am 2004;33:75-92.

22. Unwin N, Shaw J, Zimmet P, Alberti KG. Impaired glucose tolerance and impaired fasting glycaemia: the current status on definition and intervention. Diabet Med 2002;19;708-23.

23. de Vegt F, Dekker JM, Jager A. Relation of impaired fasting and postload glucose with incident type 2 diabetes in a Dutch population: the Hoorn Study. JAMA 2001;285:2109-13.

24. Qiao Q, Lindstrom J, Valle TT, Tuomilehto J. Progression to clinically diagnosed and treated diabetes from impaired glucose tolerance and impaired fasting glycaemia. Diabet Med 2003;20:1027-103.

25. Samuel DJ, Hasan A, and Gunjan T. Glucoregulatory physiology in subjects with low-normal, high-normal, or impaired fasting glucose. J Clin Endocrinol Metab 2009;94:2031-6.

26. Brunzell JD, Robertson RP, Lerner RL. Relationships between fasting plasma glucose levels and insulin secretion during intravenous glucose tolerance tests. J Clin Endocrinol Metab 1976;42:222-9.

27. Utzschneider KM, Prigeon RL, Faulenbach MV. Oral disposition index predicts the development of future diabetes above and beyond fasting and 2-h glucose levels. Diabetes Care 2009;32:335-41.

28. Burke GL. Fasting plasma glucose and insulin levels and their relationship to cardiovascular risk factors in children: Bogalusa Heart Study. Metabolism 1986;35:441-6.

29. Tirosh A, Shai I, Tekes MD. Normal fasting plasma glucose levels and type 2 diabetes. N Engl J Med 2005;353:1454-62.

30. Shaw M, Savoye M, Cali A, Dziura J, Tamborlane WV, Caprio S. Effect of a successful intensive lifestyle program on insulin sensitivity and glucose tolerance in obese youth. Diabetes Care 2009;32:45-7. 